\title{
A Case Study of Project-based Learning in Structural Engineering
}

\author{
Julie Mills \\ University of South Australia
}

\begin{abstract}
Engineering education remains dominated by the "chalk and talk" technique, despite the large body of education research that demonstrates its ineffectiveness. Structural engineering education also remains dominated by this pedagogy, with a heavy emphasis on lecture-based delivery of the theories of structural analysis and the behaviour of common construction materials. The integration of these fields rarely occurs. Concern about the effectiveness of this approach has been raised by practitioners, professional bodies and educators. The use of projectbased learning is proposed as one means of overcoming these concerns, as projects enable students to understand the synthesis of structural analysis, material behaviour, constructability and economic reality that occurs in the professional practice of structural engineering.

At many institutions design projects are left to the final year of the degree and assessment weighting often heavily favours examinations over project work. This study proposed that the use of design projects in structural engineering is an effective method of learning that models industrial practice, and that projects should consequently be incorporated throughout the degree program. A case study of the effectiveness of project-based learning in structural engineering was undertaken in the third year of an undergraduate civil engineering course in South Australia. This paper discusses the development of the study, including the theoretical framework and the measures of effectiveness used. Students' and industry's perceptions of the skills necessary for successful practice in structural engineering are examined as well as the students' perceptions of the value of the course projects and other components as a means of attaining these skills. Finally, students' success in acquiring these skills through the design projects and other components of the course is evaluated.
\end{abstract}

\section{Introduction}

Structural Engineering is one of four main specialist areas of Civil Engineering (the others are geotechnical, water and transportation engineering). It may be defined as

The science and art of planning, design, construction, monitoring and inspection maintenance, rehabilitation and preservation, demolishing and dismantling of structures taking into consideration technical, economic, environmental, aesthetic and social aspects. The term "structures" includes buildings, bridges, in-ground structures, footings, frameworks and any other structures composed of any structural material. [1].

The fundamental core of structural engineering is design. To structural engineers, design is what they do when they develop the schemes for construction of a bridge or building, deciding how it 
will support the loads to which it will be subjected, whilst remaining safe and serviceable for its occupants, yet also retaining the external appearance required by the architect. It is also the products that come from these decisions and which are used to communicate the "design" to those who will actually build the structure, usually drawings, backed up by calculations and experience.

Design is mistakenly considered by some to be only "putting theory into practice". Those who hold this view believe that the application of a "correct" mathematical structural analysis will enable the accurate prediction of the stresses and strains in a structure under load and the design of the structural members can then follow.

However, structural analysis is just one component of the design process. Analysis of a structure does not occur until after numerous design decisions have been made, many of them based on the economics of the particular structural problem. Practicing structural engineers know that good structural design depends on numerous other factors or types of knowledge apart from mathematical structural analysis. Some examples are:

- Rules of thumb

- The numerous empirical data and rules associated with Codes of Practice

- The properties of particular materials

- Factors of safety

- Intuitive knowledge of structural behaviour

- Experience

- Engineering judgement [2]

Hence successful structural design requires an engineer to possess theoretical, practical and experiential knowledge as well as skills such as innovation, translating concepts into details, and the ability to create designs which can be built easily and cheaply.

Although design is the primary role of structural engineers, there is continued concern that it is not properly taught or given sufficient emphasis in current university programs [e.g. 3,4]. The typical structural engineering specialisation within the majority of civil engineering degree programs involves two "streams" of courses. One relates to the physics and mathematical modelling of structures and how they behave, and the other relates to the behaviour of the various construction materials and how they are utilised in structures. The first course group is frequently labelled "structural analysis" and the second "structural materials or design". Different universities will place different emphasis on each stream, and design projects will also be given varying emphasis within the second stream. It is rare that the analysis and materials streams are synthesised. There are shortcomings to this traditional approach in preparing students for professional practice on graduation. Addis has summarised many of these issues as follows: 
The academic environment is not directly concerned with the realms of practice and designing real structures and works of civil engineering. The primary emphasis is, therefore, the teaching of the theory upon which practice is supposed to depend. It usually goes without question that this is a suitable preparation for its being put into practice.... students concentrate too much on the quantitative and theoretical aspects of engineering and too little on certain other aspects. They consequently graduate lacking real understanding, for instance, of the physical behaviour of structures, not appreciating how the theory they have learnt can be used, and having little idea of what design really is. [2]

A major part of the problem is that many faculty who have been career academics, have little personal experience in doing design in practice. [e.g. 5,6]. Design was traditionally taught in an experiential mode, as is very commonly seen in Architecture programs. Design was often seen as a "soft" course by the engineering scientists who felt that they taught the "real" content. However, there is increasing pressure from professional accreditation bodies and some engineering academics to increase the design emphasis in all engineering programs, including structural engineering. Dym asserts that design taught in a project-, team-based approach addresses many of the concerns of accrediting bodies and practitioners. "It helps engineering students develop skills in some of the related "arts" of being an engineer, including working in teams, making presentations to a variety of audiences, and managing design engineering projects." [7].

This discussion should not be interpreted to mean that the teaching of design and theory are mutually exclusive. Clearly it is still necessary for engineers to learn theories of structural analysis and material behaviour. However, it is suggested that the teaching of theory should be incorporated within design experiences, thus providing the synthesis of understanding that is currently missing in most structural engineering programs.

\section{Project-based Learning in Engineering}

The term "project" is universally used in engineering practice as a "unit of work", usually defined on the basis of the client. Almost every task undertaken in professional practice by an engineer will be in relation to a project. Projects will have varying time scales. A project such as the construction of a large dam or power station may take several years, whilst other engineers may be involved on numerous small projects for various clients at any given time. Projects will have varying complexity, but all will relate in some way to the fundamental theories and techniques of an engineer's discipline specialisation. Small projects may only involve one area of engineering specialisation, but larger projects will be multi-disciplinary, not only involving engineers from different specialisations, but other professional and non-professional personnel and teams. It is expected that an engineer would progress during their career from involvement in the technical aspects of small projects or small components of large projects under supervision after graduation, to the eventual management of large projects with a limited personal involvement in the technical design components.

Successful completion of projects in practice requires the integration of all areas of an engineer's undergraduate training. It has therefore been proposed by many in industry that projects should be a major component of student learning during that training, hence the term "project-based learning". Projects should gradually increase in complexity over the duration of the course, with technical as well as communication, teamwork and managerial skills being introduced and then 
revisited through successive projects. Ideally projects should integrate all technical specialisations within a particular engineering field as well as other professional areas through the use of multidisciplinary teams (e.g. architects, builders, civil engineers, environmental scientists, economists). However, if this is not feasible at a particular institution, individual lecturers or specialisation teams can still implement project-based learning within their own courses.

Project-based learning is sometimes used interchangeably with the term problem-based learning, a more familiar term to many educators. However, in the engineering context, they are not the same things. Problem-based learning was introduced in the area of medical education in the 1960 's and has become widespread in that area and related health professions since that time. The major objection raised against the use of problem-based learning in engineering, as compared with medicine, is that engineering requires knowledge of core areas such as mathematics and physics, and that the nature of engineering knowledge is hierarchical and sequential, rather than encyclopaedic like medicine. Consequently, undergraduate engineering degrees tend to spend early years on core knowledge courses taught in discrete units, and then continue to teach discrete areas or engineering specialisations as separate courses, rather than integrated wholes.

A comparison of problem-based and project-based learning in engineering at tertiary level was made by Perrenet et al [8]. They noted that the similarities between the two strategies are that they are both based on self-direction and collaboration, and that they both have a multidisciplinary orientation. The differences that they noted included:

- Project tasks are closer to professional reality and therefore take a longer period of time than problem-based learning problems (which may extend over only a single session, a week or a few weeks).

- Project work is more directed to the application of knowledge, whereas problem-based learning is more directed to the acquisition of knowledge.

- Project-based learning is usually accompanied by subject courses (e.g. maths, physics etc. in engineering), whereas problem-based learning is not

- Management of time and resources by the students as well as task and role differentiation is very important in project-based learning [8]

The most well known example of a project-based curriculum in engineering is at Aalborg University in Denmark, where projects and project-related courses make up 75\% of the program and project-based learning was introduced in the early 1970's [9]. Some recent Australian examples of project-based learning include Central Queensland University [10] and Monash University [11].

The difficulty in assessing the success of project-based curricula is that a comparison between project-based outcomes and traditional curriculum outcomes is not comparing apples with apples. This is summarised by Heitmann [12]: 
All too often the success and effectiveness of project orientation is measured against the cognitive and knowledge orientation of the traditional subject learning. This is not appropriate with respect to the described aims of project work. Trust in selfdetermined student learning effects is necessary as well as the development of suitable assessment procedures which do not focus on product and content mainly, but equally on skills and attitudes.

An interesting demonstration of Heitmann's point is given by Lenschow [13], in describing the outcome of a structural engineering course with 30 students, which was split into two parts. One group undertook a traditional curriculum, while the other half formed project-based learning groups and had no lectures. Each half was asked to design a concrete car park building. The traditionally taught group:

...became expert in accurate calculation of load capacity of slabs of a building, how reinforcement should be bent and placed in concrete, etc. The PBL class was most concerned with the function of the building ... traffic flow and optimum use of the slab area. It was less important to save $20 \mathrm{~mm}$ in slab thickness, while this might be a major point for the traditional class. Hence according to traditional teaching the first class acquired correct knowledge and more competence than the PBL students, while some teachers, owners and users in the market-place saw a substantial added value in the teamwork, leading to a holistic approach and solution. The two classes could not have the same exam, so a direct comparison was impossible. (p. 160)

Several evaluations have been conducted of the Aalborg University program, including comparisons with the traditional program at the Danish Technological University (DTU). Some of these are described in detail in Fink [14] and Kjersdam [15]. The 1998 evaluation used selfevaluation reports from each institution, a questionnaire to graduates of each school and interviews with representatives from industry leaders, as well as a site visit to each school. The findings were that both programs were excellent but the graduates focussed on different skills. Aalborg graduates were stronger in team skills, communication, ability to carry out a total project and generally more adaptable and thus, more directly employable on graduation. DTU graduates were stronger in engineering fundamentals and more capable of independent work, but it was perceived that they would generally require more on-the-job training. The Aalborg graduates themselves, 3 to 4 years after graduation, expressed quite strongly that they felt they had been well prepared for the profession and better prepared than those from the traditional program. They also felt that the weight of project work in the program was sufficient and that the project work was the main source of their professional knowledge, as well as where they had learned to apply it. Differences in the retention rates and completion times between Aalborg and DTU have been noted. The Aalborg dropout rate is $20-25 \%$ and most occurs in the first year. In the traditionally taught Danish programs the dropout rate is approximately $40 \%$ [16, p. 104].

\section{Theoretical framework of the study}

The theoretical framework that best encapsulates the beliefs about knowledge and learning which underlie project-based learning is that of constructivism. Constructivism maintains that knowledge is not received passively but is built up by the cognizing subject [17]. It is an active process in which teaching is integral with supporting learning; listening to and understanding students' knowledge concepts, adopting teaching approaches that promote conceptual change and assessing learning in a manner that supports these changes. 
The constructivist view of teaching and learning focuses not on teacher performance and tools, but on students' learning. Teaching strategies are not thought of in terms of teaching methods but in the aims for student learning and the extent to which a particular strategy achieves the principles of effective instruction within a particular context [18]. The constructivist definition of curriculum has been stated as "the set of learning experiences which enable the learners to develop their understanding" [19]. This view may mean that content must in fact be reduced. As expressed by Starr and Krajcik [20], "this deeper understanding can only occur by "doing less", in other words by stressing the importance of understanding a few important concepts well, as opposed to covering many concepts.

The study was developed around a conceptual framework for educational evaluation adopted by the International Association for the Evaluation of Education [21, 22] and developed further in Treagust [23] and Van den Akker [24]. The framework differentiates between the intended, implemented, perceived and achieved curriculum. The curriculum has been defined concisely by Taba [25] as a "plan for learning" and elaborated further by Walker [26] as "the content and purpose of an educational program together with their organization." The four aspects that were used in evaluating the curriculum's effectiveness in this study are defined below.

The intended curriculum is defined as the original vision underlying a curriculum, which may be in the form of a national curriculum document or accreditation criteria. Within a particular class this may be presented in the form of a course or subject document. The implemented curriculum is the actual instructional process as implemented. The perceived curriculum is the actual learning experiences as perceived or experienced by the students. Finally, the achieved curriculum is defined as the resulting learning outcomes of the students.

\section{Case study design and procedures}

The study was conducted with an undergraduate civil engineering course at the University of South Australia, Building for People. The course is taught in Semester 1 of the third year of a four-year undergraduate course and is preceded in the degree program by fundamental courses in Mechanics and Stress Analysis. Building for People introduces students to the analysis and design of structures in steel and reinforced concrete, it is the first exposure of the students to "real" structural engineering. The class size in the study was 21 students. The course involved an average of 5 contact hours per week over 13 weeks, consisting of approximately 2 hours of lectures, 1.5 hours of tutorials or practicals and 1.5 hours of design project sessions. Assessment was based on $50 \%$ examination, $40 \%$ for 2 design projects and $10 \%$ for practicals. Design projects were predominantly carried out by students working in pairs, although some elected to work individually.

A case study method was selected for this research as the most appropriate technique because the situation being researched was a natural setting with one class of students and involving a multitude of variables. The definition of a case study that was adopted is one defined by Anderson [27] that was developed from Merriam [28] and Yin [29], i.e. "A case study is a holistic research method that uses multiple sources of evidence to analyze or evaluate a specific phenomenon or instance. Most case study research is interpretive and seeks to bring to life a case. It often, but not exclusively, occurs in a natural setting and it may employ qualitative and/or quantitative methods and measures." [27, p. 152]. It was not possible to separate and 
control particular variables in the routine "classroom" setting, as required for a scientific experiment type approach. In addition, the author had dual roles in the study as both researcher and "teacher" hence their influence was an unavoidable component of the situation being studied [30]. The case being studied was "bounded" or specific, i.e., it was restricted to the particular cohort of students and their study of a particular course. Multiple sources of data and data collection methods were employed and triangulation [31] was used to interpret and develop generalisations from the study.

A literature review was undertaken to develop the intended curriculum for the course taking into account the needs of the engineering industry and the outcomes of several reviews of engineering education that have been conducted in various countries in recent years (e.g. [32 - 37]). However, the most formal guidance on "what industry requires" from graduate structural engineers is provided by the legal registration requirements for practice and the membership requirements of the relevant specialist learned societies in each country. Registration for professional practice as a structural engineer is not yet universally required in Australia, but several states have adopted registration on the National Professional Engineers Register (NPER), in the practice area of structural engineering, as satisfying their legislative requirements in this area. Membership of the Structural College of the Institution of Engineers, Australia is also considered as full professional standing in structural engineering. The Institution of Engineers, Australia is also accredited to assess eligibility for registration on NPER, hence their guidelines for assessment can be considered to satisfy both standards.

The intended curriculum that was finally adopted for the study was based on the guidelines for skills and knowledge of structural engineering developed by the Structural College of the Institution of Engineers, Australia [38], which were also very similar to those of the Institution of Structural Engineers in the United Kingdom [39]. Although one of the requirements of the applicant for registration is that they have a minimum of three years practical experience in structural engineering since graduation, the guidelines can be used as an indication of the expected knowledge of a graduate engineer. The intended learning outcomes for the course incorporated both the technical skills from these guidelines and generic skills based on the accreditation requirements of both the IE Aust [40] and the Accreditation Board of Engineering and Technology in the USA [41]. The intended curriculum was documented in the course handout and project handouts to students, as well as the curriculum and lesson plans developed by the author. The technical and generic skills adopted for the study are listed in the perceived curriculum evaluation questionnaire that is included as Appendix A.

A detailed intended curriculum plan was developed that tabulated for each generic or technical skill the intention, the implementation and the assessment. Questions used by the author to develop this plan were - "What am I trying to achieve?" (the intention); "How do I propose to do this?" (the implementation) and "How will I tell if this has been achieved?" (the assessment). For each skill the implementation may have been through any or all of the projects, lectures, tutorials, practicals or site visits. In determining assessment, some skills were specifically mapped to marks allocated in the projects, using a detailed marking scheme that was issued to the students. Similarly some skills were mapped to specific marks in exam questions. Other skills were assessed by overall achievement in the course, and others were not specifically 
assessed in this course, but assisted in developing a knowledge base that will be assessed in later courses. An extract from the intended curriculum plan is included as Appendix B.

The implemented curriculum, i.e. what was actually taught, was documented through the author's own observations and field notes, as well as videotaping of project sessions. The perceived curriculum was evaluated by several means including student journals, classroom observation, interviews with individual students, and the course evaluation instrument. In addition, a specific questionnaire framed around the same learning objectives as those articulated in the intended curriculum was used to assess the importance of each skill as perceived by the student, and the component(s) of the course where they believed that they developed each skill (refer Appendix A). The first part of the perceived curriculum evaluation instrument was also administered to several industry representatives who make up the Board of the Structural College of the Institution of Engineers, Australia. This Board is responsible for assessing the qualifications and experience of engineers who wish to be registered to practice as Structural Engineers in Australia. This was used to enable a comparison of students' perceptions with those of senior industry representatives.

The course evaluation instrument administered to the students was a standard 5-point Likert scale questionnaire required to be completed for all courses taught at the university. The first 10 statements are generic to all courses and relate to teaching standards, assessment and feedback, workload and clarity of information provided. The other 10 statements were selected by the author from an allowed set of standard questions and focussed more on the information of interest to the study. Two open-ended optional response questions were also included.

The achieved curriculum was evaluated by analysing student's marks in the aspects of the projects and exam that were specifically mapped to the intended curriculum, as well as the student journals and interviews. An extract from the mapped marking schemes for one of the projects as well as the examination is included as Appendix C.

\section{Results \\ Perceived curriculum}

Student perceptions: The overall average response for the twenty statements on the course evaluation instrument was $4.1,(1=$ strongly disagree to $5=$ strongly agree $)$ indicating that students were generally satisfied with the course. Those statements with average response scores of 4.4 or higher included "It is clear to me that the assessment methods in this course require me to understand the material that has been presented", "In this course I have been encouraged to develop my own learning skills" and "I can see the relevance of this course for my degree program." These statements could be interpreted as supporting the relevance and effectiveness of the project-based approach to learning, since it accounted for $40 \%$ of the assessment, $30 \%$ of the formal contact time and probably $90 \%$ of the non-contact time expected of the students in the course. Those statements with the lowest average scores of 3.3 and 3.4 were "There was generally enough time to understand the things we have to learn" and "The workload for this course was reasonable given my other study commitments." This could indicate that the projects placed a high workload on the students, or possibly that the depth of understanding demanded by the project-based approach required more time and work than the students were used to from their previous courses. 
Responses to the optional open-ended question "Which specific aspects of the course have you found most useful for your own learning and why?" were made by 13 of the 21 students. Nine of these specifically mentioned the design projects including "Design project - enables a good concept of knowledge and application to be practiced" and "I have found the project based learning most useful as it provides a realistic application of knowledge acquired, and an effective learning regime."

Comparison with the industry group's perceptions: The most important generic skills required of a graduate structural engineer (5-point Likert scale group average result in brackets) were considered by the industry group to be the ability to: "Apply knowledge of basic science and engineering fundamentals" (5); "Communicate effectively, not only with engineers but also with the community at large" (4.8) and "Undertake problem identification, formulation and solution" (4.8). The latter two of these items were ranked by the students as first and second most important (4.6 and 4.4 respectively). The industry group's top two ranked technical skills were: "Understanding of the importance of all three basic principles of structure - stability, strength, serviceability" (5) and "Understanding loads and how their effects are modelled in structural analysis" (5). These skills were ranked second and fourth most important (at 4.5 and 4.3) by the students, with their most important skill (4.6) being "The need to produce engineering solutions that are functional and economical as well as technically correct", which was rated at 4.5 by the industry group.

The students undertook the questionnaire at the conclusion of the course. The close agreement between their responses and those of the industry group indicate that the students gained a high level of understanding from the course of those skills that will be important in professional practice as a structural engineer.

Perceptions of the design projects as a learning opportunity Students were also asked to indicate from which areas of the course they believed that they gained the same list of generic and technical skills that they had rated for importance. The four areas were: lectures/ tutorials/ practicals; design projects; self-study (other than project work); and no opportunity in the course (see Appendix A). Design projects were rated as the area where most students perceived that they had gained these skills for 15 of the 20 listed skills, and as the second ranked area for 4 of the remaining skills, with the last skill considered to have "no opportunity in this course". All of the skills ranked by the industry group and the students as being most important were perceived as being gained most through the design projects.

\section{Achieved curriculum}

Of the 21 students enrolled in the course, 18 achieved $50 \%$ or more in the overall assessment and 3 students failed $(47 \%, 45 \%$ and $8 \%$ (the last student did not sit the exam or submit the second project)). Class average marks in the major components of the course are shown in Table 1 below. 
Table 1: Class average assessment

\begin{tabular}{lcc}
\hline \multicolumn{1}{c}{ Course component } & Marks & $\begin{array}{c}\text { Percentage } \\
(\mathbf{\%})\end{array}$ \\
\hline Steel design project & $16.3 / 20$ & 81.7 \\
\hline Concrete design project & $15.2 / 20$ & 76.0 \\
\hline Practicals (laboratories) & $5.9 / 10$ & 59.3 \\
\hline Steel exam component & $9.6 / 20$ & 48.1 \\
\hline Concrete exam component & $14.9 / 30$ & 49.7 \\
\hline \multicolumn{1}{r}{ Overall } & $61.9 / 100$ & 61.9 \\
\hline
\end{tabular}

These marks indicate that students generally achieved much better marks in the design projects than in the examinations. This raises the long-standing debate about the value of examinations versus continuous assessment in evaluating learning outcomes, with supporters of examinations believing that if students can't produce correct solutions under pressure then they can't have learnt the material, while supporters of continuous as sessment methods such as projects argue that examinations support surface learning while projects promote deeper learning, which is necessary for professional engineering practice. Students certainly have the opportunity to revisit and upgrade their original solutions during the course of a project as they discuss and compare their outcomes with the lecturer and other students, which is likely to lead to higher assessment results (although this could be considered to be proportional to the effort made by undertaking this review and upgrade process). However, another factor that also needs to be considered in these results is that students who knew that they had already achieved a near pass from their results in the projects and practicals may have chosen to focus on other courses with higher examination components to maximise their overall success, and not studied particularly hard for the exam in this course. This possibility was not specifically evaluated in the study.

With regard to the technical and generic skills that were used to develop the intended curriculum and which were mapped to specific marks in the projects and examination, the class average results were as given in Table 2. Some explanation of this table is necessary. It was derived by first considering for each of the technical and generic skills what was the most relevant formal measure of effective achievement of that skill. For some skills this was through the mapped marking plans for the projects and the examination. For other skills the measure of achievement was taken to be the area of the course where students perceived they had gained the skill, as indicated by the perceived curriculum evaluation, usually the overall project results. Several skills used the same measure of achievement. For those skills that were mapped to specific marks in the project or examination, the project mark sheet and examination script of each student was analysed, and the marks for each skill component totalled to arrive at a score of the possible marks for that skill. This was then converted to a percentage. The average of these results for all students is given in Table 2. The "Possible marks of 100" column is there to indicate the relative proportion of the overall assessment that related to the particular skill, and the "Class average $(\%)$ " is the average percentage of those possible marks achieved by the class. It should also be noted that only 20 students were considered in these results since one student did not complete project 2 or the examination. Since many of the measures of effectiveness were based on overall projects or the examination, that student's results for project 1 were disregarded, in the interests 
of presenting realistic averages for the class who completed the entire course. This accounts for the slight discrepancies in class average marks between Tables 1 and 2.

Table 2: Class average assessment for technical and generic skills

\begin{tabular}{|c|c|c|c|c|c|c|}
\hline & \multicolumn{2}{|c|}{ Examination } & \multicolumn{2}{|c|}{ Design project } & \multicolumn{2}{|c|}{ Overall } \\
\hline & $\begin{array}{l}\text { Poss. } \\
\text { Marks } \\
\text { of } 100\end{array}$ & $\begin{array}{l}\text { Class } \\
\text { Ave. } \\
(\%)\end{array}$ & $\begin{array}{l}\text { Poss. } \\
\text { Marks } \\
\text { of } 100\end{array}$ & $\begin{array}{l}\text { Class } \\
\text { Ave. } \\
(\%)\end{array}$ & $\begin{array}{l}\text { Poss. } \\
\text { Marks } \\
\text { of } 100\end{array}$ & $\begin{array}{l}\text { Class } \\
\text { Ave. } \\
(\%)\end{array}$ \\
\hline Generic skills & & & & & & \\
\hline Apply basic fundamentals & & & & & 100 & 64.8 \\
\hline Communicate effectively & & & 9 & 79.7 & & \\
\hline Technical competence & & & & & 100 & 64.8 \\
\hline Problem identification & 50 & 51.5 & 40 & 81.8 & & \\
\hline Systems approach & & & 40 & 81.8 & & \\
\hline Teamwork & & & 40 & 81.8 & & \\
\hline Sustainable development & & & 40 & 81.8 & & \\
\hline Lifelong learning & & & 40 & 81.8 & & \\
\hline Technical skills & & & & & & \\
\hline $\begin{array}{l}\text { Stability, strength, } \\
\text { serviceability }\end{array}$ & 37 & 52.8 & 19.8 & 82.1 & & \\
\hline Understand loads & 2.5 & 83.5 & 10 & 82.5 & & \\
\hline Materials & & & & & 100 & 64.8 \\
\hline Analysis techniques & 10.5 & 39.2 & 1.2 & 83.1 & & \\
\hline Design & 37 & 52.8 & 19.8 & 82.1 & & \\
\hline Australian Standards & & & 40 & 81.8 & & \\
\hline Engineering drawings & & & 9 & 79.7 & & \\
\hline
\end{tabular}

A significant point to note from this analysis is that very few of the generic or technical skills could be mapped to specific marks in formal assessments. For the examination, only three technical skills were specifically examined and the projects specifically assessed two further skills of engineering drawings and technical communication. However, the projects overall were considered to be good indicators of achievement in many of the other technical and generic skills as indicated by the perceived curriculum analysis.

These results taken on their own indicate that students acquired the generic and technical skills more successfully through the design projects than through the examinations. However, the numbers alone do not indicate the full story. Comments in the students' journals, interviews with volunteer students and the author's observation journal record of questions asked by students during the projects all reinforce the finding that the design projects were the most effective means of achieving deeper and more lasting skill and knowledge acquisition or learning 
outcomes in the course. The following extract from an interview conducted with a volunteer student a month after the completion of the course examination summarises this finding:

\begin{abstract}
Author: "So you're saying you think you retained the knowledge better than when you just study for exams".

Student: "Yes, definitely because it's a long term process, whereas when you study for an exam you sort of cram two weeks and you've got other classes you study for, so you spend like five days on it than you do the exam, and it's gone, finished-whereas for the project you spend ten weeks on it or 8 weeks on it and you work enormous hours on it, like coming in and checking on it so you know what you're doing. Maybe your work may not be $100 \%$ correct but you've got a general picture of the procedure. So I mean, I can't even remember what's in the exam, and what questions you gave but if you ask me what the project steps were, I'd tell you step by step."
\end{abstract}

\title{
Summary
}

Overall the study has shown that students' perceptions of the generic and technical skills that will be important for successful structural engineering practice agreed closely with those of a senior industry group in that area of engineering. In addition the students indicated overwhelmingly that they perceived the design project component of the curriculum in the case study course as being the most effective component for gaining these skills. This perception was supported by the results achieved, which were significantly higher for the project components than the examination components of the course, and by the author's observations, student journals and interview records.

\section{Bibliography:}

1. Institution of Engineers, Australia, College of Structural Engineers, Structural Engineering as a career. Career information brochure. Canberra: Institution of Engineers. (1998).

2. Addis, W., Structural Engineering: The Nature of theory and design. Ellis Horwood Ltd, England. (1990).

3. Beaufait, F.W., “Teaching structural engineering in year 2000.” In Ang, A. \& Villaverde, R. (Eds.) Structural engineering in natural hazards mitigation. ASCE. p.1657-1662. (1993).

4. Tietz, B., "Design education.” The Structural Engineer, 75(18), 325-326 (1997).

5. Suprenant, B.A., "What is a structural engineer?” ASCE Civil Engineering, 57(8), 6 (1987).

6. Lahoud, P.M., "Structural engineering education practice and liability." In Education and continuing development for the civil engineer. Proceedings of the National Forum April 17-20, 1990, American Society of Civil Engineers. 108-114. (1990).

7. Dym, C.L., "Learning engineering: Design, languages and experiences." Journal of Engineering Education, 88(2), 145-148. An expanded version is available on-line at http://www2.hmc.edu/ dym/EngrngEd.html (1999).

8. Perrenet, J.C., Bouhuijs, P.A.J. \& Smits, J.G.M.M., "The suitability of problem-based learning for engineering education: theory and practice." Teaching in higher education, 5(3), 345-358 (2000). 
9. Kolmos, A., "Reflections on project work and problem-based learning." European Journal of Engineering Education, 21(2). 141-148 (1996).

10. Wolfs, P.J., Howard, P., Vann, A. \& Boyd, P., "Experiences with the first year of a project based engineering degree." In Howard, P., Swarbrick, G. \& Churches, A. (eds.) Waves of Change, 10th AAEE Conference, 28-30 September, 1998, Gladstone, Australia. pp. 59-63 (1998).

11. Hadgraft, R.G. and Young, W., Teaching Strategy. Department of Civil Engineering, Monash University. Available on line at http://www.eng.monash.edu.au/civil/teaching/vision (1998).

12. Heitmann, G., "Project-oriented study and project-organized curricula: A brief review of intentions and solutions." European Journal of Engineering Education 21(2), 121-131 (1996).

13. Lenschow, R. (1998). From teaching to learning: A paradigm shift in engineering. European Journal of Engineering Education. 23(2), 155-161.

14. Fink, F.K. (1999). Integration of engineering practice into curriculum - 25 years of experience with problem based learning. In 29th ASEE/IEEE Frontiers in Education Conference, (pp. 7-12, Session 11a2). San Juan, Puerto Rico. Available at http://fie/engrng.pitt.edu/fie99/.

15. Kjersdam, F. (1994). Tomorrow's engineering education - The Aalborg experiment. European Journal of Engineering Education, 19(2), 197-203.

16. Creese, R. (1987). A project-centred engineering program. Engineering Education, 78(2), 100-104.

17. Treagust, D.F., Duit, R. \& Fraser, B. J. (1996). Improving teaching and learning in science and mathematics. New York: Teachers College Press.

18. Ramsden, P. (1992). Learning to teach in higher education. London: Routledge.

19. Driver, R. \& Oldham, V. (1986). A constructivist approach to curriculum development in science. Studies in Science Education, 13, 105-122.

20. Starr, M. L., \& Krajcik, J. S. (1990). Concept maps as a heuristic for science curriculum development: Toward improvement in process and product. Journal of Research in Science Teaching, 27(10), 987-1000.

21. Keeves, J. P., "The IEA science project: Science achievement in three countries - Australia, the Federal Republic of Germany, and the United States." Implementation of curricula in science education. Cologne: German Commission for UNESCO. 158-178, (1972).

22. Rosier, M. J., \& Keeves, J. P. (Eds.). (1991). The IEA study of science I: Science education and curricula in twenty-three countries. London: Pergamon Press.

23. Treagust, D. F., "Exemplary practice in high school biology classes." In K. G. Tobin \& B. J. Fraser (Eds.) Exemplary practice in science and mathematics education. Perth, W.A.: Curtin University of Technology. 29-44. (1987).

24. Van den Akker, J., "The science curriculum: Between ideals and outcomes." In B.J. Fraser \& K.G. Tobin (Eds.) International handbook of science education. Dordrecht, The Netherlands: Kluwer Academic Publishers. 421-447, (1998).

25. Taba, H. (1962). Curriculum development: Theory and practice. New York: Harcourt Brace, Jovanovitch.

26. Walker, D. (1992). Methodological issues in curriculum research. In P. W. Jackson (ed.) Handbook of research on curriculum. (pp. 98-118). New York: Macmillan. 
27. Anderson, G. (1998). Fundamentals of educational research. (2nd ed.) London: The Falmer Press.

28. Merriam, S. (1988). Case study research in education: A qualitative approach. San Francisco: Jossey-Bass.

29. Yin, R.K. (1994). Case study research: Design and methods. (2nd ed.) Beverly Hills, CA: Sage.

30. Wong, E.D. (1995). Challenges confronting the researcher/teacher: Conflicts of purpose and conduct. Educational Researcher, 24 (3), 22-28.

31. Mathison, S. (1988). Why triangulate? Educational Researcher, 17(2), (13-17).

32. Henshaw, R. (1991). Desirable attributes for professional engineers. In Agnew, J.B. \& Creswell, C. (Eds.) Broadening Horizons of Engineering Education, 3rd Annual conference of Australasian Association for Engineering Education. 15-18 December, 1991. University of Adelaide. pp. 199-204.

33. Todd, R. H., Sorensen, C. D. \& Magleby, S. P. (1993). Designing a capstone senior course to satisfy industrial customers. Journal of Engineering Education, 82(2). 92-100.

34. Lang, J.D., Cruise, S., McVey, F.D. \& McMasters, J. (1999). Industry expectations of new engineers: A survey to assist curriculum designers. Journal of Engineering Education, 88(1), 43-51.

35. Back, W.E. \& Sanders, S.R. (1998). Industry expectations for engineering graduates. Engineering, Construction and Architectural Management, 5 (2), 137-143.

36. Institution of Engineers, Australia (1996). Changing the culture: Engineering education into the future. Review report. Canberra: Institution of Engineers.

37. American Society of Engineering Education (1994). The Green Report: Engineering education for a changing world. ASEE, Washington DC. Available on-line at http://www.asee.org/pubs/html/greenworld.htm

38. Institution of Engineers Australia, College of Structural Engineers, Guidance notes for membership reviewers. (Issue 2/Revision 0, 1 November 2000).

39. Institution of Structural Engineers, Core objectives for the Initial Professional Development (IPD) of Chartered Structural Engineers. (Issue AM.P3. $1^{\text {st }}$ edition) (2000).

40. Institution of Engineers, Australia (1999). Manual for the accreditation of professional engineering programs. Revised: 7 October 1999. Canberra: Institution of Engineers.

41. ABET (1996). Engineering Criteria 2000 (2nd ed.) Engineering Accreditation Commission of the Accreditation Board of Engineering and Technology, Baltimore, Maryland.

\section{Biographical Information}

JULIE MILLS is a Senior Lecturer in Civil Engineering at the University of South Australia. She has been lecturing since 1996 and prior to that, she worked for several years in industry as a structural engineer. Julie has a BE (Hons) from Adelaide University, M. Tech. from Deakin University and is currently undertaking a $\mathrm{PhD}$ at Curtin University in the area of engineering education. Her primary research interests are in cold-formed steel structures and engineering education. 


\section{Appendix A}

\section{BUILDING FOR PEOPLE N - Perceived curriculum evaluation June, 2001}

Imagine that immediately following graduation, you are employed as a graduate Structural Engineer in the structural design team of a consulting firm such as Connell Wagner or Ove Arup. Please answer the following questions based on the scale:

\begin{tabular}{|c|c|c|c|c|c|}
\hline Very unimportant & Unimportant & Neutral & Important & Very important & Not applicable \\
\hline 1 & 2 & 3 & 4 & 5 & $X$ \\
\hline
\end{tabular}

A. How important do you believe the following general skills and attributes will be in this position?

\begin{tabular}{|c|c|c|c|c|c|c|}
\hline Ability to apply knowledge of basic science and engineering fundamentals. & 1 & 2 & 3 & 4 & 5 & $\mathrm{X}$ \\
\hline $\begin{array}{l}\text { 2. Ability to communicate effectively, not only with engineers but also with the } \\
\text { community at large. }\end{array}$ & 1 & 2 & 3 & 4 & 5 & $\mathrm{X}$ \\
\hline In-depth technical competence in structural engineering & 1 & 2 & 3 & 4 & 5 & $\mathrm{X}$ \\
\hline Ability to undertake problem identification, formulation and solution. & 1 & 2 & 3 & 4 & 5 & $\mathrm{X}$ \\
\hline Ability to utilise a systems approach to design and operational performance. & 1 & 2 & 3 & 4 & 5 & $\mathrm{X}$ \\
\hline $\begin{array}{l}\text { 6. Ability to function effectively as an individual and in multi-disciplinary and } \\
\text { multi-cultural teams, with the capacity to be a leader or manager as well as an } \\
\text { effective team member. }\end{array}$ & 1 & 2 & 3 & 4 & 5 & $\mathrm{X}$ \\
\hline $\begin{array}{l}\text { 7. Understanding of the social, cultural, global and environmental responsibilities } \\
\text { of the professional engineer, and the need for sustainable development. }\end{array}$ & 1 & 2 & 3 & 4 & 5 & $\mathrm{X}$ \\
\hline 8. Understanding the principles of sustainable design and development. & 1 & 2 & 3 & 4 & 5 & $\mathrm{X}$ \\
\hline $\begin{array}{l}\text { 9. Understanding of professional and ethical responsibilities and commitment to } \\
\text { them. }\end{array}$ & 1 & 2 & 3 & 4 & 5 & $\mathrm{X}$ \\
\hline 10. Expectation of the need to undertake lifelong learning and capacity to do so. & 1 & 2 & 3 & 4 & 5 & $\mathrm{X}$ \\
\hline
\end{tabular}

B. How important do you believe the following technical skills or abilities will be in this position?

\begin{tabular}{|c|c|c|c|c|c|c|}
\hline $\begin{array}{l}\text { 11. Understanding of the importance of all three basic principles of structure - } \\
\text { stability, strength, serviceability. }\end{array}$ & 1 & 2 & 3 & 4 & 5 & $\mathrm{X}$ \\
\hline $\begin{array}{l}\text { 12. Understanding loads (gravity, wind etc.) and how their effects are modelled in } \\
\text { structural analysis. }\end{array}$ & 1 & 2 & 3 & 4 & 5 & $\mathrm{X}$ \\
\hline $\begin{array}{l}\text { 13. Understanding the need to produce engineering solutions that are functional and } \\
\text { economical as well as technically correct. }\end{array}$ & 1 & 2 & 3 & 4 & 5 & $\mathrm{X}$ \\
\hline $\begin{array}{l}\text { 14. Having good knowledge of the properties of each of the materials normally used } \\
\text { - steel, concrete. }\end{array}$ & 1 & 2 & 3 & 4 & 5 & $\mathrm{X}$ \\
\hline $\begin{array}{l}\text { 15. Understanding the need for alternative load paths and the need to avoid } \\
\text { progressive collapse mechanisms. }\end{array}$ & 1 & 2 & 3 & 4 & 5 & $\mathrm{X}$ \\
\hline 16. Having the ability to "visualise" failure mechanisms. & 1 & 2 & 3 & 4 & 5 & $\mathrm{X}$ \\
\hline $\begin{array}{l}\text { 17. Having a good knowledge of modern techniques of structural analysis, design } \\
\text { and construction. }\end{array}$ & 1 & 2 & 3 & 4 & 5 & $\mathrm{X}$ \\
\hline 18. Having a broad knowledge of relevant Australian standards. & 1 & 2 & 3 & 4 & 5 & $\mathrm{X}$ \\
\hline $\begin{array}{l}\text { 19. Having knowledge of available analysis and design aids including computer } \\
\text { programs and design manuals. }\end{array}$ & 1 & 2 & 3 & 4 & 5 & $\mathrm{X}$ \\
\hline 20. Having short-cut methods to check computer program outputs. & 1 & 2 & 3 & 4 & 5 & $\mathrm{X}$ \\
\hline $\begin{array}{l}\text { 21. Having the ability to communicate design solutions through sketches and } \\
\text { engineering drawings }\end{array}$ & & & & & & \\
\hline
\end{tabular}


C. Where do you believe that you gain skill or knowledge in these areas in the course Building for People N (noting that not all of the areas may be covered in this course)? Please tick boxes in each line (you may have from 1 to 3 ticks in any line).

\begin{tabular}{|c|c|c|c|c|}
\hline & $\begin{array}{c}\text { Lectures/ } \\
\text { Tutorials/ } \\
\text { Practicals } \\
\text { (formal } \\
\text { contact } \\
\text { hours) }\end{array}$ & $\begin{array}{c}\text { Design } \\
\text { Project } \\
\text { (formal } \\
\text { contact and } \\
\text { outside hours } \\
\text { work) }\end{array}$ & $\begin{array}{c}\text { Self-study } \\
\text { (any other } \\
\text { work outside } \\
\text { formal } \\
\text { contact } \\
\text { hours) }\end{array}$ & $\begin{array}{l}\text { No } \\
\text { opportunity } \\
\text { in this } \\
\text { course }\end{array}$ \\
\hline $\begin{array}{l}\text { 22. Ability to apply knowledge of basic science and } \\
\text { engineering fundamentals. }\end{array}$ & & & & \\
\hline $\begin{array}{l}\text { 23. Ability to communicate effectively, not only with } \\
\text { engineers but also with the community at large. }\end{array}$ & & & & \\
\hline 24. In-depth technical competence in structural engineering & & & & \\
\hline $\begin{array}{l}\text { 25. Ability to undertake problem identification, formulation } \\
\text { and solution. }\end{array}$ & & & & \\
\hline $\begin{array}{l}\text { 26. Ability to utilise a systems approach to design and } \\
\text { operational performance. }\end{array}$ & & & & \\
\hline $\begin{array}{l}\text { 27. Ability to function effectively as an individual and in } \\
\text { multi-disciplinary and multi-cultural teams, with the } \\
\text { capacity to be a leader or manager as well as an } \\
\text { effective team member. }\end{array}$ & & & & \\
\hline $\begin{array}{l}\text { 28. Understanding of the social, cultural, global and } \\
\text { environmental responsibilities of the professional } \\
\text { engineer, and the need for sustainable development. }\end{array}$ & & & & \\
\hline $\begin{array}{l}\text { 29. Understanding the principles of sustainable design and } \\
\text { development. }\end{array}$ & & & & \\
\hline $\begin{array}{l}\text { 30. Understanding of professional and ethical } \\
\text { responsibilities and commitment to them. }\end{array}$ & & & & \\
\hline $\begin{array}{l}\text { 31. Expectation of the need to undertake lifelong learning } \\
\text { and capacity to do so. }\end{array}$ & & & & \\
\hline $\begin{array}{l}\text { 32. Understanding of the importance of all three basic } \\
\text { principles of structure - stability, strength, } \\
\text { serviceability. }\end{array}$ & & & & \\
\hline $\begin{array}{l}\text { 33. Understanding loads (gravity, wind etc.) and how their } \\
\text { effects are modelled in structural analysis. }\end{array}$ & & & & \\
\hline $\begin{array}{l}\text { 34. Understanding the need to produce engineering } \\
\text { solutions that are functional and economical as well as } \\
\text { technically correct. }\end{array}$ & & & & \\
\hline $\begin{array}{l}\text { 35. Having good knowledge of the properties of each of the } \\
\text { materials normally used - steel, concrete. }\end{array}$ & & & & \\
\hline $\begin{array}{l}\text { 36. Understanding the need for alternative load paths and } \\
\text { the need to avoid progressive collapse mechanisms. }\end{array}$ & & & & \\
\hline 37. Having the ability to "visualise" failure mechanisms. & & & & \\
\hline $\begin{array}{l}\text { 38. Having a good knowledge of modern techniques of } \\
\text { structural analysis, design and construction. }\end{array}$ & & & & \\
\hline $\begin{array}{l}\text { 39. Having a broad knowledge of relevant Australian } \\
\text { standards. }\end{array}$ & & & & \\
\hline $\begin{array}{l}\text { 40. Having knowledge of available analysis and design aids } \\
\text { including computer programs and design manuals. }\end{array}$ & & & & \\
\hline $\begin{array}{l}\text { 41. Having short-cut methods to check computer program } \\
\text { outputs. }\end{array}$ & & & & \\
\hline $\begin{array}{l}\text { 42. Having the ability to communicate design solutions } \\
\text { through sketches and engineering drawings }\end{array}$ & & & & \\
\hline
\end{tabular}




\section{Appendix B}

\section{Extract from Curriculum Plan incorporating Intended curriculum, Implementation of this}

and Assessment in Building for People N, 2001

\begin{tabular}{|c|c|c|c|}
\hline $\begin{array}{l}\text { Generic } \\
\text { skills }\end{array}$ & $\begin{array}{l}\text { Intention - what am I } \\
\text { trying to achieve? }\end{array}$ & $\begin{array}{l}\text { Implementation - how do I } \\
\text { propose to do this }\end{array}$ & $\begin{array}{l}\text { Assessment - how will I tell } \\
\text { if this has been achieved? }\end{array}$ \\
\hline $\begin{array}{l}\text { 1. Apply } \\
\text { basic } \\
\text { fundamentals }\end{array}$ & $\begin{array}{l}\text { This is generic throughout the } \\
\text { course. Students have } \\
\text { previously studied } \\
\text { mathematics, physics, } \\
\text { chemistry, engineering } \\
\text { materials, structural } \\
\text { mechanics. This course is the } \\
\text { first opportunity to apply that } \\
\text { fundamental knowledge to } \\
\text { structural design. }\end{array}$ & $\begin{array}{l}\text { Throughout the course - } \\
\text { lectures, tutorials, practicals, } \\
\text { projects }\end{array}$ & $\begin{array}{l}\text { Through all components of } \\
\text { assessment - exam, projects } \\
\text { and prac reports. Difficult to } \\
\text { separate proportions of skill } \\
\text { learnt through each } \\
\text { component. Overall } \\
\text { assessment is probably the } \\
\text { only valid measure. }\end{array}$ \\
\hline $\begin{array}{l}2 . \\
\text { Communicate } \\
\text { effectively }\end{array}$ & $\begin{array}{l}\text { Verbal communication: only } \\
\text { informal in this course, no } \\
\text { oral presentations etc. } \\
\text { Written/graphic } \\
\text { communication: students to } \\
\text { become familiar with } \\
\text { acceptable presentation of } \\
\text { calculations and drawings. }\end{array}$ & $\begin{array}{l}\text { Written/graphic - students } \\
\text { required to present their } \\
\text { calculations and drawings of } \\
\text { design project to a } \\
\text { professional standard. Some } \\
\text { instruction/references in } \\
\text { project handouts, verbal } \\
\text { references in class, feedback } \\
\text { in assessment. }\end{array}$ & $\begin{array}{l}\text { Marks assigned to drawings } \\
\text { in project, as well as overall } \\
\text { presentation }\end{array}$ \\
\hline \multicolumn{4}{|c|}{ Other skills 3 and 4 , omitted from this extract } \\
\hline \multicolumn{4}{|c|}{\begin{tabular}{l|l} 
Technical & \\
skills & \\
\end{tabular}} \\
\hline $\begin{array}{l}\text { 11. Stability, } \\
\text { strength, } \\
\text { serviceability }\end{array}$ & $\begin{array}{l}\text { An understanding of the } \\
\text { importance of each } \\
\text { component and that you can't } \\
\text { just satisfy one and not } \\
\text { others. How to satisfy the } \\
\text { requirements of each } \\
\text { component. }\end{array}$ & $\begin{array}{l}\text { Lectures/tutorials - } \\
\text { techniques for satisfying each } \\
\text { component presented, as well } \\
\text { as examples demonstrating } \\
\text { that all are considered in } \\
\text { design } \\
\text { Projects - requirement of } \\
\text { design for each component } \\
\text { within the project, and } \\
\text { marking scheme } \\
\text { demonstrates that each must } \\
\text { be considered for design of } \\
\text { the structure. }\end{array}$ & $\begin{array}{l}\text { Exams - marks allocated for } \\
\text { specific sections of questions } \\
\text { relating to each component. } \\
\text { Projects - marks allocated } \\
\text { specifically to each } \\
\text { component within the } \\
\text { marking scheme. }\end{array}$ \\
\hline 12. Loads & $\begin{array}{l}\text { An understanding of how to } \\
\text { determine the design loads on } \\
\text { a structure. An understanding } \\
\text { of Limit State Design. }\end{array}$ & $\begin{array}{l}\text { Lecture presented on Limit } \\
\text { State Design and Wind loads. } \\
\text { Project - requirement for } \\
\text { calculation of loads in both } \\
\text { projects }\end{array}$ & $\begin{array}{l}\text { Projects - marks allocated } \\
\text { specifically for load } \\
\text { determination. (not assessed } \\
\text { in exam) }\end{array}$ \\
\hline $\begin{array}{l}13 . \\
\text { Functional } \\
\text { and economic }\end{array}$ & $\begin{array}{l}\text { An understanding that other } \\
\text { factors influence design than } \\
\text { just the numbers, particularly } \\
\text { construction issues. This is } \\
\text { developed further in later } \\
\text { courses. }\end{array}$ & $\begin{array}{l}\text { This will be discussed } \\
\text { informally in lectures and } \\
\text { project sessions. } \\
\text { Site visit used to illustrate } \\
\text { these issues }\end{array}$ & Not specifically assessed \\
\hline
\end{tabular}




\section{Appendix C}

\section{Extracts from mapped marking schemes for project 1 and the examination}

Note: Students received a similar scheme for each project in the handout, but the last column was "Anticipated completion date" rather than "Skill type \& No.". This was used to give the students an idea of the time schedule they should aim for within the project.

\section{Project 1 - allocation of marks to generic and technical skills}

\begin{tabular}{|c|c|c|}
\hline Item - Project 1 & Allocated \% & Skill type \& No. \\
\hline $\begin{array}{l}\text { Wind load determination, consisting of: } \\
\text { - } \quad \text { Design wind speed } \\
\text { - } \quad \text { External pressures } \\
\text { - } \quad \text { Internal pressures }\end{array}$ & $\begin{array}{l}\mathbf{1 4} \\
3 \\
7 \\
4\end{array}$ & T12(b) \\
\hline $\begin{array}{l}\text { Overall building stability under wind i.e. roof and wall bracing, } \\
\text { consisting of: } \\
\text { - layout and member load determination } \\
\text { - tension members design } \\
\text { - compression members design }\end{array}$ & $\begin{array}{l}10 \\
4 \\
3 \\
3\end{array}$ & $\begin{array}{l}\mathrm{T} 11(\mathrm{~b}) \& \mathrm{~T} 17(\mathrm{~d}) \\
\mathrm{T} 11(\mathrm{~b}) \& \mathrm{~T} 17(\mathrm{~d}) \\
\mathrm{T} 11(\mathrm{~b}) \& \mathrm{~T} 17(\mathrm{~d})\end{array}$ \\
\hline $\begin{array}{l}\text { Rafter, R1 design, consisting of: } \\
\text { - } \quad \text { determine design loads for strength \& serviceability } \\
\text { - } \quad \text { serviceability design } \\
\text { - } \quad \text { strength design - section moment capacity } \\
\text { - } \\
\text { strength and stability design - member moment capacity } \\
\text { (including effective lengths) for worst up and down load } \\
\text { combinations }\end{array}$ & $\begin{array}{c}15 \\
5 \\
3 \\
2 \\
5\end{array}$ & $\begin{array}{c}\mathrm{T} 12(\mathrm{~b}) \\
\mathrm{T} 11(\mathrm{~b}) \& \mathrm{~T} 17(\mathrm{~d}) \\
\mathrm{T} 11(\mathrm{~b}) \& \mathrm{~T} 17(\mathrm{~d}) \\
\mathrm{T} 11(\mathrm{~b}) \& \mathrm{~T} 17(\mathrm{~d})\end{array}$ \\
\hline
\end{tabular}

\section{Exam questions - allocation of marks to generic and technical skills}

\begin{tabular}{|l|c|c|}
\hline Question & Allocated \% & Skill type \& no. \\
\hline $\begin{array}{l}\text { Steel question 1 } \\
\text { - Determine design load and bending moment } \\
\text { - Check section capacity, member capacity and combined } \\
\text { actions }\end{array}$ & $\mathbf{1 4}$ & T12(a) \\
& 12 & T11(a) \& T17(c) \\
\hline $\begin{array}{l}\text { Steel Question 2(a) } \\
\text { - Determine shear force and bending moment }\end{array}$ & $\mathbf{1 6}$ & T17(a) \\
\hline $\begin{array}{l}\text { Steel Question 2(b) } \\
\text { - determine design moments and shears }\end{array}$ & 14 & T11(a) \& T17(c) \\
- Design bolts and plate using AISC charts & $\mathbf{1 0}$ & T17(a) \\
& 3 & T11(a) \& T17(c) \\
\hline
\end{tabular}

